\title{
CDISC SDTM Asthma Findings About Test Code Terminology
}

National Cancer Institute

\section{Source}

National Cancer Institute. CDISC SDTM Asthma Findings About Test Code Terminology. NCI Thesaurus. Code C132313.

Terminology associated with the asthma findings about test code codelist of the Clinical Data Interchange Standards Consortium (CDISC) Study Data Tabulation Model (SDT M). 